\title{
The Utilization of SPEEDLINE DOTS-CULIA for Students with Special Educational Needs
}

\author{
Yoong Soo May, Nor Azmidy Ismail
}

To Link this Article: http://dx.doi.org/10.6007/IJARBSS/v11-i10/10380

DOI:10.6007/IJARBSS/v11-i10/10380

Received: 04 August 2021, Revised: 30 August 2021, Accepted: 18 September 2021

Published Online: 20 October 2021

In-Text Citation: (May \& Ismail, 2021)

To Cite this Article: May, Y. S., \& Ismail, N. A. (2021). The Utilization of SPEEDLINE DOTS-CULIA for Students with Special Educational Needs. International Journal of Academic Research in Business and Social Sciences, 11(10), $975-981$.

\section{Copyright: (c) 2021 The Author(s)}

Published by Human Resource Management Academic Research Society (www.hrmars.com) This article is published under the Creative Commons Attribution (CC BY 4.0) license. Anyone may reproduce, distribute, translate and create derivative works of this article (for both commercial and non-commercial purposes), subject to full attribution to the original publication and authors. The full terms of this license may be seen

at: http://creativecommons.org/licences/by/4.0/legalcode

Vol. 11, No. 10, 2021, Pg. 975 - 981

Full Terms \& Conditions of access and use can be found at http://hrmars.com/index.php/pages/detail/publication-ethics 


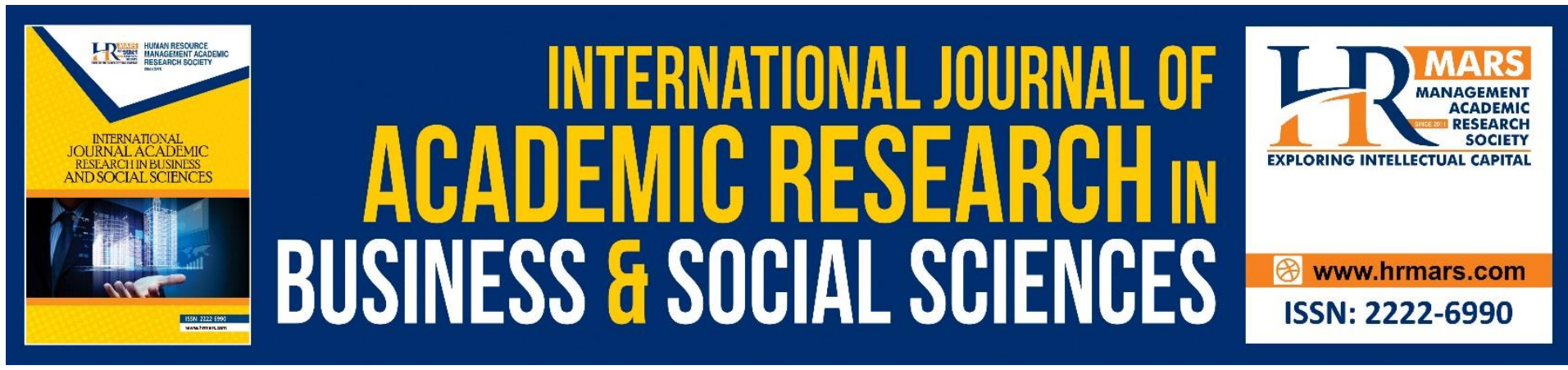

\title{
The Utilization of SPEEDLINE DOTS-CULIA for Students with Special Educational Needs
}

\author{
Yoong Soo May \\ Department of Special Education, Faculty of Human Development Universiti Pendidikan \\ Sultan Idris, Malaysia.
}

Nor Azmidy Ismail

Sekolah Kebangsaan Bukit Beruang, KM 7.2, Kampung Bukit Beruang, 75450 Bukit Beruang, Melaka.

\begin{abstract}
United Nations Convention on the Rights of Persons with Disabilities (UNCRPD) mentioned that students with special educational needs have a basic human right to be educated in mainstream schools. These students learn at a relatively slow pace and might need more time to build a basis of arithmetic facts if compare with the typical students in mainstream classrooms. The difficulties in Mathematics happen among the students, especially for students with dyscalculia. The innovation of SPEEDLINE DOTS-CULIA aims to assist teachers and students to enhance their teaching and learning of the basic arithmetic skills in a quick and an effective way. The purpose of this study is to utilize SPEEDLINE DOTS-CULIA to improve the addition and subtraction skills for students with special educational needs. SPEEDLINE DOTS-CULIA is an easy to learn method and suitable with the cognitive development level for the students. The method employed in this study is single-group experiment. A pre-test had been carried out in order to select the students who have not mastered in addition and subtraction skills. Ten participants were selected among the students in special education class. After the pre-test, three weeks of intervention was carried out to the participants, followed by a post-test. Data was analysed using descriptive statistics. The findings showed that there were improvements in achievement for the participants. As a conclusion, SPEEDLINE DOTS-CULIA has improved the addition and subtraction skills among the students with special educational needs. This study implicated that the utilization of SPEEDLINE DOTSCULIA is effective in teaching and learning of basic arithmetic skills and it is applicable for all special educational needs students.
\end{abstract}

Keywords: Special Educational Needs, Dyscalculia, Mathematics, Addition, Subtraction

\section{Introduction}

The 2030 Agenda for Sustainable Development is providing inclusive and equitable quality education at all levels, from early childhood, primary, secondary, tertiary, technical, and vocational training for all, included students with special educational needs (United Nations, 2018). In Malaysia, educational services for students with special educational needs are being 
provided by the Ministry of Women, Family and Community Development and the Ministry of Education (Ibrahim et al., 2019). In year 2019, there are 16.87 percent of the UPSR candidates failed in Mathematics subject. In another word, there is a total of 72,812 out of 431,610 Year Six Pupils obtained an E for their Mathematics subject during UPSR examination (Ministry of Education Malaysia, 2019). This is a very serious issue because Mathematics is a compulsory subject in primary and secondary school curriculum in Malaysia (Yoong, 2020).

The teachers need to fully understand the basis of support for students with special educational needs (Hameed, 2017). Besides, teachers need to be creative and innovative in order to improve the learning of special educational needs students. This happens especially in Mathematics as it is often a difficult task for special education needs students, especially those with dyscalculia. Hence, teachers need to come out with innovative ideas and products in order to improve the mathematical skills among the special educational needs students.

\section{Background}

The special education curriculum depends on three main principles; (1) comprehensive and integrated education; (2) good and meaningful learning; and (3) lifelong education (Yunus \& Ahmad, 2019). One of the issue related special education supports is the collective planning between the classroom teacher and special education teacher (Ferreira, 2017). Special education is an education specially designs for the students who have special educational needs. Teachers need to be very patient because these students are often considerably behind in their learning ability, as compared with their peers (Yoong \& Ahmad, 2020).

Mathematics is one of the most important subjects yet some students might face difficulties in learning it (Yoong \& Ahmad, 2018). Arithmetic and the study of number shall be focused because that's where Mathematics education starts and where learners first experience failure (Chinn, 2021). Five levels of sophistication of addition strategies used by students are; (1) count all; (2) count on from the first number; (3) count on from the larger number; (4) recall or retrieval of a known fact; and (5) deriving the fact from a known fact (Thompson, 1999; Chinn \& Ashcroft, 2017).

On the other hand, the simplest process of subtraction is change by taking away. It may initially seem simple to understand, as does the outcome of becoming less, or even none left. But observing what is happening may be more confusing for students than we think because the answers are often arrived at in different ways, such as taking some away, separating a group and counting the remainder, and counting back as objects are removed. (Staves, 2019). Dot subtraction is thought to be executed through calculation rather than retrieval, more so than the other measured arithmetic types (Van der Ven et al., 2017).

Hence in this study, the researchers had developed an innovative way for the learning of addition and subtraction suitable with the cognitive development level for special educational needs students. The purpose of this study is to utilize SPEEDLINE DOTS-CULIA to improve the addition and subtraction skills for students with special educational needs.

\section{Research Questions}

One research question in this study is

1. Is there any improvement in addition and subtraction among students with special educational needs after using SPEEDLINE DOTS-CULIA? 


\section{Methodology}

The purpose of this study is to utilize SPEEDLINE DOTS-CULIA to improve the addition and subtraction skills for students with special educational needs. SPEEDLINE DOTS-CULIA is an easy to learn method. It needs not any specific devices, tools, or even teaching aids. The students only need to have the prior knowledge of counting forwards from 0 to 9 and the knowledge of counting backwards from 9 to 0 . Based on the purpose of this study, the researcher employed a single-group experimental design. Ten participants had been selected to involve in the experimental group.

\section{Research Design}

Table 1 shows the model of single-group experimental design in this study. The participants had gone through a pre-test, then an intervention using SPEEDLINE DOTS-CULIA. After that, the participants had gone through a post-test. The purpose of pre-test and post-test is to compare the achievement of participants after utilization of SPEEDLINE DOTS-CULIA in learning addition and subtraction.

Table 1. Single-Group Experimental Design

\begin{tabular}{|c|c|c|}
\hline Pre-test & Intervention & Post-test \\
\hline $\mathrm{T} 1$ & SPEEDLINE DOTS-CULIA & T2 \\
\hline
\end{tabular}

Table 2 shows the three weeks intervention plan for SPEEDLINE DOTS-CULIA. During the first week, the students learnt to count in ascending order from 0 to 9 and count in descending order from 9 to 0 . During the second week, students learnt to solve addition operation using SPEEDLINE DOTS-CULIA. During the third week, students learnt to solve subtraction operation using SPEEDLINE DOTS-CULIA.

Table 2. Three Weeks Intervention Plan

\begin{tabular}{|c|l|}
\hline Week & \multicolumn{1}{|c|}{ Intervention (Activity) } \\
\hline 1 & $\begin{array}{l}\text { - Students learn to count in ascending order from } 0 \text { to } 9 . \\
\text { - Students learn to count in descending order from } 9 \text { to } 0 .\end{array}$ \\
\hline 2 & $\begin{array}{l}\text { - Students learn to solve addition operation using SPEEDLINE DOTS-CULIA. } \\
\text { - Students draw dots under the first addend according the second addend } \\
\text { given. } \\
\text { - Students count the dots in ascending order from } 0 \text { to } 9 \text { and restart from } 0 . \\
\\
\text { - When count to 0, students must add one more dot under the digit on the left } \\
\text { hand side. } \\
\text { - Students write the last number under the dots. }\end{array}$ \\
\hline 3 & $\begin{array}{l}\text { - Students learn to solve subtraction operation using SPEEDLINE DOTS-CULIA. } \\
\text { - Students draw dots under the minuend according to the subtrahend given. } \\
\text { - Students count the dots in descending order from } 9 \text { to } 0 \text { and restart from } 9 . \\
\text { - When count to 9, students must add one more dot under the digit on the left } \\
\text { hand side. } \\
\text { - Students write the last number under the dots. }\end{array}$ \\
\hline
\end{tabular}

\section{Participants of the Study}

The selection of participants in this study is students in special education class with different special educational needs. These students are having special educational needs such as slow learners, autisms, hyperactive, dyslexia, dyscalculia, and down syndrome. Ten students had 
been selected from a national school in Malacca state. All of them are ten years old, and are study in Year Four. The school was selected because there was students with special educational needs who fulfilled the criteria as the according to the specific purpose of this study.

\section{Results}

The improvement of students had been determined through comparison of the means between pre-test and post-test for the participants. It is to ensure that the mean score of the post-test is higher than the mean score of the pre-test. The intervention had been carried out for a three weeks period.

Table 3 shows the results of pre-test and post-test. Based on the table, the average score for post-test is 22.3 percent, whereas the average score for post-test is 80.2 percent. Overall, all of the students had achieved an improvement after using SPEEDLINE DOTS-CULIA. The average improvement for the students is 57.9 percent.

Table 3. Results of Pre-test and Post-test

\begin{tabular}{|c|c|c|c|c|c|}
\hline No. & Student & Gender & Pre-test (\%) & Post-test (\%) & Results (+/-) \\
\hline 1. & S01 & Male & 30 & 94 & +64 \\
\hline 2. & S02 & Male & 24 & 82 & +58 \\
\hline 3. & S03 & Male & 18 & 74 & +56 \\
\hline 4. & SO4 & Male & 26 & 88 & +62 \\
\hline 5. & S05 & Male & 16 & 68 & +52 \\
\hline 6. & S06 & Male & 26 & 80 & +54 \\
\hline 7. & S07 & Male & 35 & 96 & +61 \\
\hline 8. & S08 & Male & 20 & 78 & +58 \\
\hline 9. & S09 & Male & 10 & 66 & +56 \\
\hline 10. & S10 & Female & 18 & 76 & +58 \\
\hline \multicolumn{3}{|c|}{ Average } & 22.3 & 80.2 & +57.9 \\
\hline
\end{tabular}

Figure 1 shows the score of pre-test and post-test for the pupils. Since all the scores in posttest are higher than the scores in pre-test, hence all students had been improved after using SPEEDLINE DOTS-CULIA intervention. In another word, there is an improvement in addition and subtraction among students with special educational needs after using SPEEDLINE DOTSCULIA. 


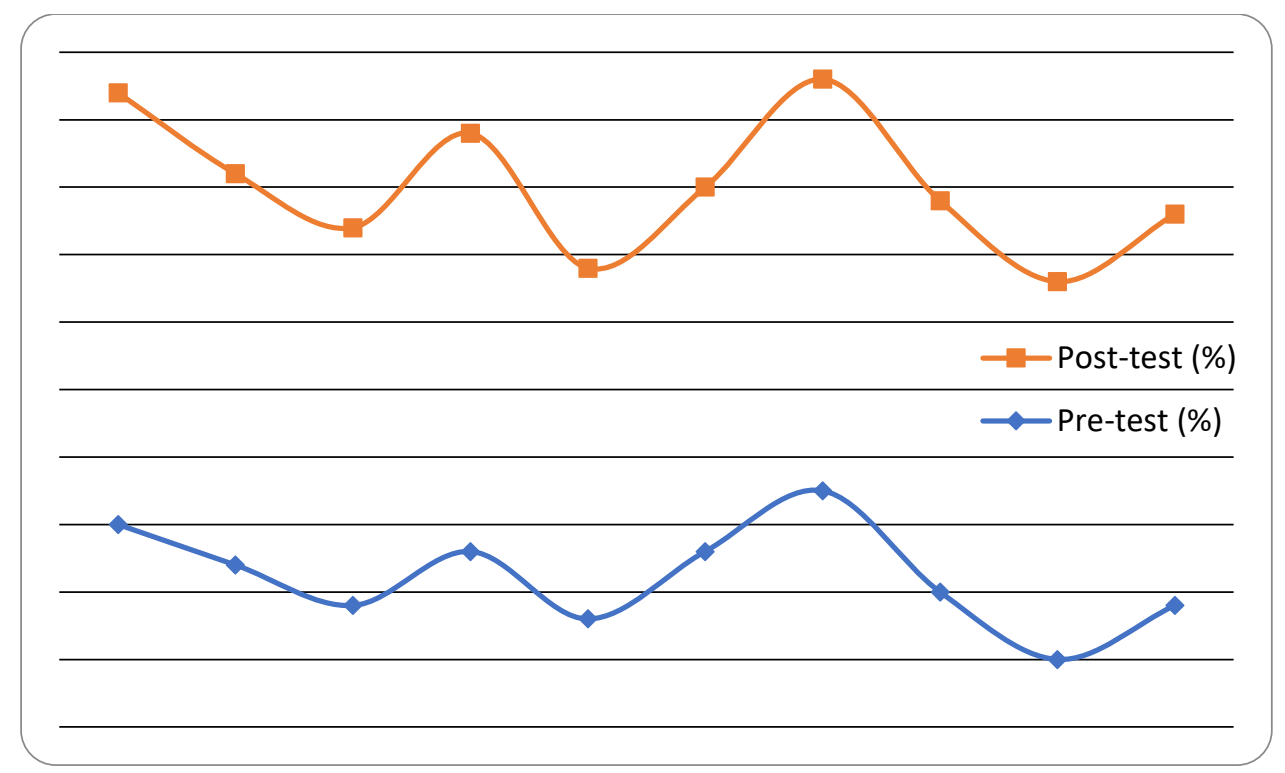

Figure 1. Score of Pre-test and Post-test for the Students

\section{Conclusion}

In a nutshell, for the students with special educational needs, teachers need to know their ability level and design the teaching and tasks according to their levels (Yoong \& Ahmad, 2020). These students should receive a quality service even in special education classes (Ahmad \& Yoong, 2018). This is in line with the fourth goal of Sustainable Developmental Goals (SDGs) which stated that quality education should be provided to all.

The results of single group experiment showed that there is a difference between the mean of pre-test and post-test for addition and subtraction skills. The data had demonstrated that SPEEDLINE DOTS-CULIA is effective to improve the basic arithmetic skills for students with special educational needs. The implication of this study is SPEEDLINE DOTS-CULIA should be applied for all special educational needs students such as dyscalculia, slow learners, autisms, hyperactive, down syndrome, and so on. The future researchers are recommended to focus on 21st century learning (PAK 21) and The Fourth Industrial Revolution (IR 4.0) so that this teaching and learning method of SPEEDLINE DOTS-CULIA will be more interesting and effective to special educational needs students in learning of Mathematics. Lastly, SPEEDLINE DOTS-CULIA is also believed to be able to bring huge impact on these students as they can apply this basic counting knowledge into their daily livings.

\section{Corresponding Author}

Yoong Soo May

Department of Special Education Faculty of Human Development Universiti Pendidikan

Sultan Idris Malaysia

Email: soomayyoong@gmail.com

\section{References}

Ahmad, N. A., \& Yoong, S. M. (2018). Challenges in preparing teachers for inclusive education and its impacts to students with learning disabilities. International Journal of Academic Research in Progressive Education and Development, 7(3), 569-581.

Chinn, S. (2021). How to Teach Math: Understand Learner's Needs. London: Routledge. 
Chinn, S., \& Aschcroft, R. E. (2017). Mathematics for Dyslexics and Dyscalculics: A Teaching Handbook. United Kingdom: Wiley Blackwell.

Ferreira, J. M. (2017). What is special in special education from the inclusive perspective? International Journal of Early Childhood Special Education, 9(1), 50-65.

Hameed, S. (2017). Teaching and supporting children with special educational needs and disabilities in primary schools. International Journal of Disability, Development and Education, 64(6), 665-666.

Ibrahim, H., Mokshein, S. E., Anal, A., \& Jabar, S. A. (2019). Assessment for children with special educational needs. Jurnal Pendidikan Bitara UPSI, 7(1), 250-271.

Ministry of Education Malaysia. (2019). Pelaporan Pentaksiran Sekolah Rendah 2019. Retrieved from: https://www.moe.gov.my/muat-turun/laporan-dan-statistik/lp/3056pelaporan-pentaksiran-sekolah-rendah-2019/file

Staves, L. (2019). Very Special Maths: Developing Thinking and Maths Skills for Pupils with Severe or Complex Learning Difficulties. London: Routledge.

United Nations. (2018). Transforming our world: the 2030 agenda for Sustainable Development. A New Era in Global Health, 529-568.

Van der Ven, F., Seger, E., Takshima, A., \& Verhoeven, L. (2017). Effects of a tablet game intervention on simple-addition and subtraction fluency in first graders. Computers in Human Behavior, 72, 200-207.

Yoong, S. M. (2020). An Introduction: What do you know about dyscalculia? In Habidin, N.F., Ong, S.Y.Y., Chik, T.W.T, \& Muhammad, U.A. (Eds.). The Revolution in Social Research and Education (pp. 82-88). Tanjung Malim: Kaizentrenovation Sdn. Bhd.

Yunus, H., \& Ahmad, N. A. (2019). A conceptual framework for META ProBaca Module in improving reading comprehension and reading fluency. International Journal of Academic Research in Business and Social Sciences, 9(11), 1187-1200.

Yoong, S. M., \& Ahmad, N. A. (2018). A conceptual framework for DoCtor WoRM's Module in improving multiplication skills among Year Four low achievers. International Journal of Academic Research in Business and Social Sciences, 8(4), 946-957.

Yoong, S. M., \& Ahmad, N. A. (2020). A view on theories and models in the study of dyscalculia. International Journal of Academic Research in Business and Social Sciences, 9(3), 128-137.

Yoong, S. M., \& Ahmad, N. A. (2020). The needs and significance to design and develop a Dyscalculia checklist. Malaysian Science and Mathematics Education Journal, 10(2), 814. 